\title{
Stress and Job Performance of Healthcare Workers amidst COVID-19 Pandemic: The Mediating Role of Burnout
}

\author{
Tri Siwi Agustina a*, Putri Dian Rarastanti a, Arif Fatah Hidayat a \\ a Postgraduate School, Universitas Airlangga, Indonesia \\ * Corresponding email: siwi@feb.unair.ac.id \\ do) http://dx.doi.org/10.22515/shirkah.v6i3.379
}

\begin{tabular}{|c|c|}
\hline ARTICLE INFO & ABSTRACT \\
\hline $\begin{array}{l}\text { Keywords: } \\
\text { Burnout; COVID-19 Pandemic; } \\
\text { Healthcare Workers; Job } \\
\text { Performance; Stress } \\
\text { Article history: } \\
\text { Received: } 15 \text { February } 2021 \\
\text { Revised: } 04 \text { June } 2021 \\
\text { Accepted: } 21 \text { August } 2021 \\
\text { Available online: } 31 \text { December } \\
2021 \\
\text { To cite in APA style: } \\
\text { Agustina, T.S., Rarastanti, } \\
\text { P.D., \& Hidayat, A. F. (2021). } \\
\text { Stress and Job Performance of } \\
\text { Healthcare Workers amidst } \\
\text { COVID-19 Pandemic: The } \\
\text { Mediating Role of Burnout. } \\
\text { Shirkah: Journal of Economics } \\
\text { and Business, 6(3), 315-335. }\end{array}$ & $\begin{array}{l}\text { Healthcare workers in hospitals are one of the frontliners in } \\
\text { handling the COVID-19 issue. However, previous studies } \\
\text { were mostly directed on doctors and nurses, albeit many } \\
\text { other workers are involved in managing the COVID-19 issue } \\
\text { at a hospital. Physical and mental work pressures in } \\
\text { performing their jobs and responsibilities potentially affect } \\
\text { their performance. This study aims to shed some light on the } \\
\text { direct influence of job stress on the job performance of } \\
\text { healthcare workers during the COVID-19 pandemic with } \\
\text { burnout as a mediating variable. This study make use of a } \\
\text { cross-sectional approach by employing a questionnaire to } \\
\text { gather the data from } 194 \text { healthcare workers at Aisyiyah } \\
\text { Ponorogo General Hospital Indonesia. Drawing on the } \\
\text { Structural Equation Modeling Partial Least Square, the } \\
\text { results reveal that (1) job stress has a negative influence on } \\
\text { the job performance of the healthcare workers, (2) job stress } \\
\text { is proven to have a positive effect on the burnout of the } \\
\text { healthcare workers, and (3) burnout is found to partially } \\
\text { mediate the effect of job stress on the job performance of the } \\
\text { healthcare workers. By referring to the compelling results, } \\
\text { valuable suggestions are offered to the hospital managers } \\
\text { and further related studies. This study's results further } \\
\text { contribute to providing recommendations for the hospital } \\
\text { management as well as the government concerning on } \\
\text { factors affecting the healthcare workers' job performance, } \\
\text { especially at the age of a crisis such as the COVID-19 } \\
\text { pandemic. }\end{array}$ \\
\hline
\end{tabular}

This work is licensed under a Creative Commons Attribution-NonCommercial 4.0 International License. 


\section{Introduction}

The complexity of handling patients who are indicated as having contact with the coronavirus disease (COVID-19) is experienced by all countries in the world, including Indonesia. Indonesia is the country with the second highest COVID-19 cases in Asia, following India which potentially becomes a new epicentrum (Bhatnagar, et al., 2021). This condition is exacerbated by the lack of health facilities and the people who do not comply with the health protocols (Ilpaj \& Nurwati, 2020). As a result, the positivity rate continues to increase by more than a thousand cases per day and the death cases are still the highest in Southeast Asia with a percentage of 9.11\% (Syafrida \& Hartati, 2020). This situation forces healthcare workers to work hard and fast in handling the cases so that the transmission does not widely-spread, every patient can recover, and there would be no more cases that result in death caused by the COVID-19 (Hira \& Amelia, 2020).

The COVID-19 pandemic situation becomes a particular concern for Indonesia, especially in the medical field. As quoted from Rizal (2020) in December 2020, 507 workers tasking in medical field passed away due to the infection (in details, doctors: 228 people, nurses: 167 people, midwives: 68 people, dentists: 13 people, medical lab technologists: 10 people, pharmacists: 6 people, radiology records: 4 people, dental therapists: 2 people, ambulance drivers: 2 people, pharmacy staff: 1 person, electromedical staff: 1 person, sanitarian: 1 person, and other health workers: 4 people). Based on the Health Care Impact Index (IPKN), data for September 2020, due to the COVID-19 Indonesia's index has reached 223, which means that Indonesia has the worst impact on healthcare workers' death in the world (Winurini, 2020). The high death rate of the medical workers was caused by the lack of personal protective equipment, lack of appropriate screening in health facilities, fatigue of medical personnel due to the growing number of COVID-19 patients and long working hours, and psychological pressure. These conditions make medical personnel very vulnerable to COVID-19 infection. The poor mental and physical conditions can eventually cause healthcare workers to fall into ill and pass away.

Kisely et al., (2020) explained that the COVID-19 pandemic caused psychological stress and posttraumatic stress in Indian Healthcare workers (HCWs). This was due to various factors, such as clinical factors (direct contact with exposed patients, feeling compelled to care for exposed patients, lack of training in handling COVID-19), personal factors (boredom in quarantine, fear of transmitting the disease to families at home), and social factors (the view of society that alienates healthcare workers because they are considered carriers of the COVID-19). From this explanation, the stress experienced by healthcare workers was disturbing and had various impacts on the life's quality of the healthcare workers. In line with this statement, Elshaer et al. (2018) stated 
that healthcare workers are very often susceptible to burnout, especially for those who treat patients directly. This is due to the intensive patient care, high mortality rate, and inappropriate job conditions in terms of high workload coupled with lack of time to adequately address the patient's needs. A survey of 2.132 nurses from all over Indonesia conducted by researchers from the Department of Mental Health Nursing, Faculty of Nursing UI in collaboration with the Research Division of the Indonesian Mental Health Nurses Association from April to May 2020 showed that more than half of healthcare workers experienced anxiety and depression, and some of them had suicidal thoughts (Winurini, 2020).

Regarding the COVID-19 pandemic, quoted from the official website of Public Relation of Indonesia University or Humas FK UI (2020), Mrs. Soemarko, the Head of the Research Team for Masters in Occupational Medicine, Faculty of Medicine, University of Indonesia stated that if a health worker feels tired emotionally, the impact that may be resulted from such a condition is a clear loss of motivation to work, so that it will affect their service quality and has an impact on the performance of medical personnel. Bakker et al. (2005) and Embriaco et al. (2007) also added that the job stress will also increase absenteeism and resignation rates.

Quoted from Rizal (2020), the Head of the Ponorogo Regency Health Office, Rahayu Kusdarini, revealed that since December 2020 the condition of COVID-19 in Ponorogo East Java province Indonesia was quite alarming (the death rate reached $5.29 \%$ ). The mortality rate exceeded the national average rate of $3.12 \%$, while the recovery rate was below the national average rate $(70 \%$ out of $80 \%)$. This condition initially caused Ponorogo to enter the COVID-19 red zone area. This was exacerbated by the condition in Dr. Hardjono General Hospital Ponorogo that there have been a number of medical personnel who were exposed to COVID-19 cases, which then resulted in the temporary closure of the hospital (Ponorogo.go.id, 2021).

In April 2020, according to the instructions of the of East Java Governor, the Aisyiyah General Hospital Ponorogo East Java province Indonesia was officially appointed as the second referral hospital for COVID-19 patients, following the Dr. Harjono General Hospital. In response to this, the manager of Aisyiyah Hospital Ponorogo provided 5 treatment rooms for the COVID-19 patients, with 15 healthcare workers who are specifically tasked with taking care of COVID-19 patients, and 1 pulmonary specialist. The results of brief preliminary interviews with 10 healthcare workers at Aisyiyah Hospital Ponorogo from early December 2020 to middle January 2021 showed that even though Aisyiyah Hospital Ponorogo is a type C hospital, it generally accepts asymptomatic to moderate COVID-19 patients.

The preliminary conducted interviews also revealed that the increasing number of COVID-19 patients being treated at the Aisyiyah Hospital Ponorogo was not 
balanced by the availability of the healthcare workers who handled the patients. Various news reporting about the high risk of being infected and even threatened their lives made the healthcare workers in Aisyiyah Hospital anxious about their safety. This circumstance triggered anxiety and fear of contacting with the virus, infecting themselves and their families, and being ostracized by their neighbors and society.

Therefore, it is a thought-provoking to study how job stress experienced by the healthcare workers and its potential to cause burnout influences the performance of the healthcare workers at Aisyiyah Hospital Ponorogo. In order to depict a complete portrayal of the impact of job stress and burnout experienced by the healthcare workers on their job performance, Ponorogo, a region in East Java province Indonesia, was chosen to be the object of this study because the city was categorized as a red zone of COVID-19 case at the time of this study was conducted. To the best of the authors' knowledge, previous studies have been extensively examined the job performance of doctors and nurses amidst the COVID-19 pandemic (Alsulimani et al., 2021; Nguyen et al., 2021; Shah et al., 2020; Talaee et al., 2020). However in reality, the healthcare workers involved in the handling process of COVID-19 patients in hospitals are not only doctors and nurses. Hence, examining those healthcare workers' (not only doctors and nurses) workloads as well as their job performances becomes an interesting issue to explore.

The previous studies further discovered that job stress could indirectly affect the healthcare workers' job performance through the mediator variables, such as public service motivation (Deng et al., 2019) and job satisfaction (Nabirye et al., 2011). Referring to the research results of Hastuti and Timming (2021), organizational support, social support, and individual differences could encourage the mental health disclosures in the workplace. As a result, it would affect various aspects such as access to accommodations and support programs, helping behaviors, psychological wellbeing, and employment success. From the previous studies' results, it is observable that the use of burnout as a mediator variable still remains unexplored. The consideration of burnout to be involved as a mediating variable of the influence of job stress on the workers' job performance is due to the burnout experienced by healthcare workers in Indonesia. While the number of COVID-19 patients keeps increasing, it did not complement the availability of the healthcare workers as the frontliners of handling the patients' recovery. In addition, referring to the opinion of Maunder et al. (2006) that the situation of pandemic, which is contagious and causes casualty on a large scale, potentially triggers job stress and burnout in the healthcare workers.

The present study is conducted based on the phenomena about stress, burnout and job performance of healthcare workers during the COVID-19 pandemic. Furthermore, it is supported by an argument that studies examining the whole 
healthcare workers, instead of only doctors and nurses, are still limited in number and need more paucity of evidence. Moreover, previous studies are also lack of scrutinizing the mediating role of job burnout on the connection between stress and job performance of healthcare workers. Therefore, this study aims to portray the influence of job stress on job performance of healthcare workers at the time of COVID-19 pandemic through burnout as a mediating variable. The results are expected to provide policy recommendations for the hospital management to concern about factors affecting the healthcare workers' job performances, especially during a global crisis like the current situation of COVID-19 pandemic.

\section{Hypotheses Development}

Job stress is a psychological process that occurs to be irritating due to the environmental pressures (Robbins \& Judge, 2015). To determine whether someone is undergone job stress, Robbins and Judge (2015) proposed some patterned symptoms namely physiological symptoms, psychological symptoms and behavioral changes. Kusumawardani et al. (2020) conducted an overview about mental health outcomes in healthcare workers. They also determined the management at the organizational and personal level. Literature source of publications were from various countries with geographical diversity, i.e. China, Italy, and Brazil. It was depicted that the COVID-19 pandemic caused healthcare workers who came across the job stress also experienced physical and mental disorders. Regarding the COVID-19 pandemic, quoted from Public Relation of Indonesia University (Humas FKUI, 2020), the Head of the Research Team for Masters in Occupational Medicine University of Indonesia stated that if a health worker feels tired emotionally, he/she may experience a clear loss of motivation to work so it will affect the service quality; as a result, it has an impact on the job performance of the medical personnel. Bakker et al. (2005) and Embriaco et al. (2007) also added that it will increase absenteeism and resignation rates. Based on the statements, a hypothesis is formulated.

H1: Job stress has a negative influence on the job performance of healthcare workers during the COVID-19 pandemic.

Burnout is a psychological pressure that has to do with stress undergone by someone, marked by some symptoms of physical, mental, and emotional fatigue (Maslach et al., 2017). According to Maslach et al. (2017), job stress is indicated by over workloads, lack of work control, work rewards, community breakdown, and being treated unfairly. These symptoms have shown to become the triggers of burnout.

A research by Talaee et al. (2020) on healthcare workers at Masih Daneshvari Hospital, Iran during the COVID-19 pandemic explained that anxiety, stress and, depression could cause burnout. Artiningsih and Chisan (2020) stated that high level of 
workload and job dissatisfaction contributed to the burnout of medical personnel in the COVID-19 pandemic. A research team from the Master of Occupational Medicine Study Program, Faculty of Medicine, University of Indonesia in 2020 conducted a survey on 1.461 healthcare workers such as doctors, specialists, dentists, nurses, midwives, pharmacists and lab analysis. At the time of COVID-19 pandemic in Indonesia, it showed the fact that a total of $82 \%$ of the healthcare workers in Indonesia had experienced moderate degree of burnout syndrome and $1 \%$ of them had severe burnout syndrome which was psychologically at risk of disrupting the quality of life and work productivity in health services. Based on these studies, a hypothesis is postulated.

H2: Job stress has a positive influence on burnout of healthcare workers during the COVID-19 pandemic.

Mangkunegara (2017) pointed out that job performance is a result of work in term of quantity and quality achieved by employees in carrying out their duties according to their responsibility. Kisa (2020) also stated that doctors and nurses as healthcare workers who directly contacted to COVID-19 patients experienced severe stress, which caused burnout and decreased the ability to carry out their tasks. Another variation of research was conducted by Deng et al. (2019) on 1.594 healthcare workers in several government hospitals in Wuhan, China. Deng et al (2019) found that job stress had a significant influence on the performance of healthcare workers mediated by the public service motivation. Denoting the idea of commitment to the public service, the pursuit of the public interest, and the desire to perform work that is worthwhile to society are proven to reduce the level of stress experienced by the healthcare workers as well as improved their job performance. Based on discussion, this study tests the following hypothesis.

H3: Burnout can mediate the influence of job stress on the job performance of healthcare workers during the COVID-19 pandemic.

\section{Method}

\section{Research Design}

The present study depicted the potential relation between stress and job performance of healthcare workers at the time of COVID-19 pandemic, with burnout as the mediating variable. This study employed quantitative method with cross-sectional approach. Job stress was an independent variable, job performance was the dependent variable, and burnout was the mediating variable. Figure 1 depicts the conceptual model of the study. 


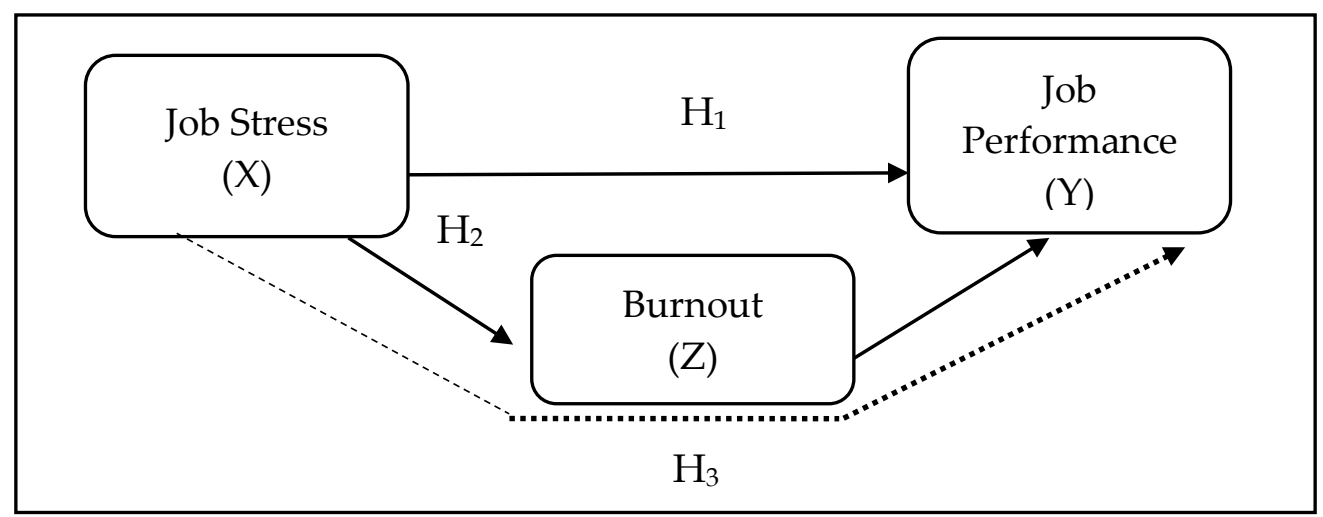

Figure 1. Conceptual Model

\section{Participants}

The population consisted of all healthcare workers at Aisyiah Hospital Ponorogo East Java Province Indonesia. The hospital became the main referral for patients with moderate and severe conditions caused by COVID-19 infection. The hospital was appointed by the provincial government following the closure of Dr. Hardjono Hospital Ponorogo, a public hospital in the region that had been initially full of the COVID-19 patients. After all, a total of 194 healthcare workers participated in this study by fulfilling the questionnaire.

\section{Instruments and Data Collection}

Job Stress, in this study, is defined as work-related pressure experienced by the healthcare workers. To measure job stress, a questionnaire adopted from Robbins and Judge (2015) consisting of 10 question items representing physiological, psychological, and behavioral dimensions was utilized. The question items were modified according to the current situation and circumstance of COVID-19 pandemic. Table 1 shows the measurement indicators of job stress.

Table 1. Measurement Indicators of Job Stress

\begin{tabular}{ll}
\hline Dimension & Indicators (Question Item) \\
\hline Physiological & $\begin{array}{l}\text { 1. During the COVID-19 pandemic, job demands do not match } \\
\text { with my skill set. }\end{array}$ \\
2. During the COVID-19 pandemic, targets and task demands \\
are too complicated which burden me. \\
3. During the COVID-19 pandemic, I am offended when a \\
coworker reprimands me.
\end{tabular}




\begin{tabular}{ll}
\hline Dimension & Indicators (Question Item) \\
\hline 3. During the COVID-19 pandemic, I always get assignments \\
with short deadlines. \\
4. During the COVID-19 pandemic, I do not understand the \\
sudden assignments. \\
\hline Behavior & $\begin{array}{l}\text { 1. During the COVID-19 pandemic, the responsibility that are } \\
\text { given to me are burdensome. }\end{array}$ \\
2. During the COVID-19 pandemic, there are delays in work \\
because the deadlines are quite long time. \\
3. During the COVID-19 pandemic, I cannot do the sudden \\
assignments.
\end{tabular}

Source: Robbins and Judge (2015)

The variable of burnout is defined as a condition felt by health workers where they had lost energy and squeezed out both physically and psychologically when they were performing their work during pandemic COVID-19. To measure burnout, 14 question items were adopted from the Masclah Burnout Inventory (MBI) which consists of emotional exhaustion, depersonalization, and decreased personal achievement. The question items were modified so that it is suitable with the condition of COVID-19 pandemic. Table 2 presents the explanation of each indicator for burnout variable.

Table 2. Measurement Indicators of Burnout

\begin{tabular}{ll}
\hline Dimension & Indicators (Question Item) \\
\hline Emotional & 1. During the COVID-19 pandemic, I feel frustrated with my job. \\
Exhaustion & 2. During the COVID-19 pandemic, I feel desperate about my \\
job. & 3. During the COVID-19 pandemic, I feel bored with my job. \\
4. During the COVID-19 pandemic, I feel tired every time I start \\
my working day. \\
5. During the COVID-19 pandemic, I feel my emotions drained \\
because of my job. \\
6. During the COVID-19 pandemic, I work too hard in this job. \\
7. During the COVID-19 pandemic, I feel blamed for what \\
happens \\
1. During the COVID-19 pandemic, I feel restless when there is \\
an unhealthy competition between coworkers. \\
2. During the COVID-19 pandemic, I feel restless if the \\
relationship between coworkers is not harmonious. \\
3. During the COVID-19 pandemic, I always get assignments \\
with short deadlines. \\
4. During the COVID-19 pandemic, I do not understand the \\
sudden assignments.
\end{tabular}




\begin{tabular}{ll}
\hline Dimension & Indicators (Question Item) \\
\hline $\begin{array}{l}\text { Decreased Personal } \\
\text { Achievement }\end{array}$ & $\begin{array}{l}\text { 1. During the COVID-19 pandemic, the responsibility that are } \\
\text { given to me are burdensome. }\end{array}$ \\
& $\begin{array}{l}\text { 2. During the COVID-19 pandemic, there are delays in work } \\
\text { because the deadlines are quite long time. } \\
\text { 3. During the COVID-19 pandemic, I cannot do the sudden } \\
\text { assignments. }\end{array}$ \\
\hline
\end{tabular}

Source: Maslach et al. (2015)

Furthermore, job performance is defined as the work results in quality and quantity achieved by the healthcare workers in carrying out their duties in accordance with the responsibilities assigned to them. To measure the performance, 10 question items that represent the dimensions of quality, quantity, reliability and attitude were adopted from Mangkunegara (2017). The question items were modified based on the condition of COVID-19 pandemic. Table 3 demonstrates the measurement indicators of job performance.

Table 3. Measurement Indicators of Job Performance

\begin{tabular}{ll}
\hline Dimension & Indicators (Question Item) \\
\hline Quality & 1. During the COVID-19 pandemic, my quality of work is as \\
good as what the hospital requires. \\
2. During the COVID-19 pandemic, I can complete every \\
assignment well. \\
3. During the COVID-19 pandemic, I work according to the \\
procedures and the schedule. \\
\hline Quantity \\
1. $\begin{array}{l}\text { During the COVID-19 pandemic, I can complete assignments } \\
\text { in the allotted time. }\end{array}$ \\
2. During the COVID-19 pandemic, I can complete assignments \\
according to my duties and responsibility set by the \\
organization. \\
1. $\begin{array}{l}\text { During the COVID-19 pandemic, I have the skill that the } \\
\text { hospital requires. } \\
\text { 2. During the COVID-19 pandemic, I strive to work my best. } \\
\text { 3. During the COVID-19 pandemic, with the experiences that I } \\
\text { have, I am able to take initiative at work. }\end{array}$ \\
1. $\begin{array}{l}\text { During the COVID-19 Pandemic, I minimize errors while } \\
\text { doing my job. } \\
\text { 2. During the COVID-19 Pandemic, with the experiences that I } \\
\text { have, I have more control over my field of work. }\end{array}$ \\
\hline Attitude
\end{tabular}

Source: Mangkunegara (2017) 
The questionnaire was distributed online using Google forms in December 2020. 194 responses were returned representing the healthcare workers at the hospital. The questionnaire items were measured using a Likert scale consisting of 5 answer choices: (1) strongly disagree, (2) disagree, (3) moderate, (4) agree, and (5) strongly agree.

\section{Data Analysis}

The data obtained from 194 healthcare workers at Aisyiyah Hospital were further analyzed using Structural equation modeling (SEM) Partial Least Square (PLS) by means of SmartPLS 3.2.9 software. Descriptive statistics in terms of percentage was administered to depict the respondents' profile. In order to empirically answer the hypotheses in this study, the analysis performed included assessing the outer model, i.e. convergent validity, construct validity, discriminant validity, and composite reliability.

The indicator is considered to be valid if its loading factor value exceeds 0.5 (Abdillah \& Jogiyanto, 2015). In the context of this study, the loading factor value for each indicator of the variables (job stress, burnout, and job performance) had been higher than 0.5 , meaning that all indicators in the forms of item questions had met the convergent validity. Moreover, a construct is considered as valid if the AVE value is higher than 0.5 (Yamin \& Kurniawan, 2011). In terms of reliability, the authors looked at the Cronbach's alpha, in which if the value was higher than 0.7 , it was considered as reliable. Furthermore, structural model measurement was conducted to predict the causality relationships between variables.

\section{Results}

\section{Descriptive Statistics}

First of all, the respondents' description is presented in Table 4 in terms of gender, age, marital status, education background, tenure, and profession. Table 4 depicts that the majority of the respondents is female (69.10\%) followed by male (30.90\%). Most of them is more than 40 years old (35.40\%) and has been already married $(69.10 \%)$. In terms of educational background, most of the respondents graduated from vocational program in health science $(51.60 \%)$, and they have been working in the hospital as healthcare workers in 5-10 years (28.00\%). They are working in the hospital in various position such as nurse, pharmacist assistant, midwives, medical record staff, physiotherapists, etc.

Table 4. Respondents' Profile

\begin{tabular}{llll}
\hline No. & Criteria & Description & Percentage \\
\hline 1 & Gender & Male & $30,90 \%$ \\
& & Female & $69.10 \%$ \\
\hline
\end{tabular}




\begin{tabular}{|c|c|c|c|}
\hline No. & Criteria & Description & Percentage \\
\hline \multirow[t]{5}{*}{2} & Age & $19-22$ years old & $1.20 \%$ \\
\hline & & $23-30$ years old & $24.80 \%$ \\
\hline & & $31-35$ years old & $30.40 \%$ \\
\hline & & $39-40$ years old & $8.10 \%$ \\
\hline & & More than 40 years old & $35.40 \%$ \\
\hline \multirow[t]{3}{*}{4} & Marital Status & Married & $69.10 \%$ \\
\hline & & Single & $13.40 \%$ \\
\hline & & Divorced & $2.10 \%$ \\
\hline \multirow[t]{4}{*}{5} & Education & Senior High School & $23.00 \%$ \\
\hline & & Vocational & $51.60 \%$ \\
\hline & & Bachelor & $24,20 \%$ \\
\hline & & Master & $1.20 \%$ \\
\hline \multirow[t]{5}{*}{6} & Length of Work & No more than 5 years & $20.50 \%$ \\
\hline & & $5-10$ years & $28.00 \%$ \\
\hline & & $10-20$ years & $23.60 \%$ \\
\hline & & $20-25$ years & $19.90 \%$ \\
\hline & & More than 25 years & $8.10 \%$ \\
\hline \multirow[t]{8}{*}{7} & Profession & Nurse & $62.90 \%$ \\
\hline & & Pharmacist Assistant & $6.70 \%$ \\
\hline & & Midwives & $5.20 \%$ \\
\hline & & General Practitioners & $3.10 \%$ \\
\hline & & Medical Record Staff & $2.60 \%$ \\
\hline & & Physiotherapists & $2.10 \%$ \\
\hline & & Other professions & $3.10 \%$ \\
\hline & & Health analyst professions & $1.00 \%$ \\
\hline
\end{tabular}

With regards to the respondents' responses, its description is presented based on the frequency and average calculation result of each categorized variable. The interval used in the categorization was obtained from the highest response value (5) minus the lowest response value (1), then divided by the number of categorization classes (5); so that the result is 0.8 . Moreover, the categorization of each dimension of the variables was carried out with the provision that the interval $1.00-1.80$ (very low), $1.81-2.60$ (low), $2.61-3.40$ (moderate), $3.41-4.20$ (high), and $2.21-5.00$ (very high). Table 5 presents the mean value of the variable job stress comprising the dimensions of physiology, psychology, and behavior. As shown in Table 5, the mean value for job stress is 2.39 , which means that the healthcare workers are having low level of workrelated pressure. Although the mean value of job stress is classified as low, we should pay more attention on the psychological dimension that is having mean value of 2.61 and considered as moderate. In other words, the healthcare workers expressed moderate level of being psychologically under work pressures and it potentially influence the quality of their services and job performances. 
Table 5. Mean Value of Job Stress

\begin{tabular}{lll}
\hline Description & Mean Value & Category \\
\hline Mean Value of Physiological Dimension & 2.20 & Low \\
Mean Value of Psychological Dimension & 2.61 & Moderate \\
Mean Value of Behavior Dimension & 2.26 & Low \\
\hline Total Mean Value of Job Stress & 2.39 & Low \\
\hline
\end{tabular}

Moreover, Table 6 demonstrates the mean value of burnout, and it is presented that the average mean value is 1.93 . It indicates that the burnout condition of the healthcare workers related to their works and responsibility during the COVID-19 pandemic is categorized as low.

Table 6. Mean Value of Burnout

\begin{tabular}{lll}
\hline \multicolumn{1}{c}{ Description } & Mean Value & Category \\
\hline Emotional Exhaustion & 2.06 & Low \\
Depersonalization & 1.75 & Very Low \\
Achievement Decrease & 1.86 & Low \\
\hline Total Mean Value of Burnout & 1.93 & Low \\
\hline
\end{tabular}

Last but not least, Table 7 depicts the mean value of job performance. It is shown that the average mean value of job performance is 3.94, indicating that the works resulted in quantity and quality achieved by the healthcare workers is considered as high. In other words, the healthcare workers at Aisyiyah hospital Ponorogo performed high level of performance in terms of their jobs and responsibilities.

Table 7. Mean Value of Job Performance

\begin{tabular}{lll}
\hline Description & Mean Value & Category \\
\hline Quality Dimension & 4.02 & High \\
Quantity Dimension & 3.93 & High \\
Reliability Dimension & 4.05 & High \\
Behavior Dimension & 3.68 & High \\
\hline Total Mean Value of Job Performance & 3.94 & High \\
\hline
\end{tabular}

\section{Measurement Model}

Table 8 presents the results of convergent validity and reliability analyses. The outer loading value of each indicator of all variables exceeded 0.50 ; hence, it is concluded that the item questions of the questionnaire are valid. Table 8 further reveals that the AVE values of the dimension of each variable are higher than 0.5 , which indicates that the variables of this study met the construct validity. Moreover, Table 8 also depicts that 
the Cronbach Alpha value of each dimension is higher than 0.7, meaning that the variables in this study already met the composite reliability. In short, we can say that all variables in this study are valid and reliable.

Table 8. Convergent Validity and Reliability

\begin{tabular}{|c|c|c|c|c|c|c|}
\hline Variable & Dimension & Indicator & $\begin{array}{l}\text { Outer } \\
\text { Loading }\end{array}$ & $\begin{array}{l}\text { Cronbach's } \\
\text { Alpha }\end{array}$ & AVE & $\begin{array}{l}\text { Composite } \\
\text { Reliability }\end{array}$ \\
\hline \multirow[t]{10}{*}{ Job Stress } & Physiological & $\mathrm{X} 1.1$ & 0,885 & 0.914 & 0,516 & 0.895 \\
\hline & & $\mathrm{X} 1.2$ & 0,851 & & & \\
\hline & & $\mathrm{X} 1.3$ & 0,775 & & & \\
\hline & Psychological & $\mathrm{X} 2.1$ & 0,778 & & & \\
\hline & & $X 2.2$ & 0,750 & & & \\
\hline & & $X 2.3$ & 0,767 & & & \\
\hline & & $X 2.4$ & 0,739 & & & \\
\hline & Behaviour & X3.1 & 0,865 & & & \\
\hline & & $\mathrm{X} 3.2$ & 0,831 & & & \\
\hline & & X3.3 & 0,803 & & & \\
\hline \multirow[t]{14}{*}{ Burnout } & Emotional & Z1.1 & 0,810 & 0.938 & 0.519 & 0.928 \\
\hline & Exhaustion & $\mathrm{Z} 1.2$ & 0,811 & & & \\
\hline & & Z1.3 & 0,827 & & & \\
\hline & & Z1.4 & 0,804 & & & \\
\hline & & Z1.5 & 0,824 & & & \\
\hline & & Z1.6 & 0,727 & & & \\
\hline & & $\mathrm{Z} 1.7$ & 0,765 & & & \\
\hline & Depersonalization & $\mathrm{Z} 2.1$ & 0,807 & & & \\
\hline & & $\mathrm{Z} 2.2$ & 0,876 & & & \\
\hline & & $\mathrm{Z} 2.3$ & 0,813 & & & \\
\hline & & $\mathrm{Z} 2.4$ & 0,863 & & & \\
\hline & Decreased & Z3.1 & 0,791 & & & \\
\hline & Achievement & $\mathrm{Z} 3.2$ & 0,879 & & & \\
\hline & & Z3.3 & 0,874 & & & \\
\hline $\mathrm{Job}$ & Job quality & $\mathrm{Y} 1.1$ & 0,858 & 0.959 & 0.703 & 0.952 \\
\hline \multirow[t]{9}{*}{ Performance } & & $\mathrm{Y} 1.2$ & 0,902 & & & \\
\hline & & Y1.3 & 0,895 & & & \\
\hline & Quantity & Y2.1 & 0,920 & & & \\
\hline & & $Y 2.2$ & 0,886 & & & \\
\hline & Reliability & Y3.1 & 0,860 & & & \\
\hline & & Y3.2 & 0,885 & & & \\
\hline & & Y3.3 & 0,894 & & & \\
\hline & Behavior & Y4.1 & 0,900 & & & \\
\hline & & $Y 4.2$ & 0,933 & & & \\
\hline
\end{tabular}

The discriminant validity is further analyzed by administering cross-loading evaluation, and the result is presented in Table 9. The result shows that the outer loading value of the item statements of each variable is higher than the other quadratic 
correlations of the model. It indicates that all constructs used in this study are different from one another. Hence, the measurement model used in this study can be considered as valid.

Table 9. Discriminant Validity

\begin{tabular}{llll}
\hline & Job Stress & Burnout & Performance \\
\hline Job Stress & $\mathbf{0 . 7 1 8}$ & & \\
Burnout & 0.717 & $\mathbf{0 . 7 2 1}$ & \\
Performance & -0.597 & -0.686 & $\mathbf{0 . 8 3 8}$ \\
\hline
\end{tabular}

\section{Structural Model}

The structural model analysis is conducted to ensure that the model developed in this study is robust. Structural model analysis is administered by considering the $\mathrm{R}^{2}$ value that describes the variation proportion the dependent variable which is explained by the independent variables. As presented in Table 10, in the path between job stress on burnout, an R-square value of 0.511 is obtained, explaining that the burnout perceptions expressed by the healthcare workers can be explained as many as $51.1 \%$ by their perceptions toward the job stress. Moreover, in the path between job stress and burnout on job performance, an R-square value of 0.488 is obtained, indicating that the perceptions of job performance earned by the healthcare workers can be explained by their perceptions toward job stress and burnout as many as $48.8 \%$; while the remaining is explained by other variables excluded in this study.

Table 10. R-Square Value

\begin{tabular}{ll}
\hline & R-square \\
\hline Job Performance & 0.488 \\
Burnout & 0.511 \\
\hline
\end{tabular}

Furthermore, this study employs the path coefficient through the bootstrapping analysis procedure to determine the relationship between the variables and test the hypotheses. Based on the hypotheses testing results presented in Table 11, the influence of job stress on job performance results in p-value $0.035(<0.05)$, which means that there is a significant negative effect of job stress on job performance of the healthcare workers. Therefore, $\mathrm{H} 1$ is supported. The influence of job stress on burnout reaches the p-value $0.000(<0.05)$, indicating that there is a significant positive impact of job stress on burnout of the healthcare workers. Hence, H2 is supported. Moreover, the impact of job stress on job performance as mediated by burnout performs p-value $0.000(<0.05)$, implying that the mediation role of burnout referring to the indirect influence is partial mediation. Thus, H3 is supported. It suggests that with or without the variable of 
burnout, job stress still has an effect on job performance.

Table 11. Hypotheses Testing Results

\begin{tabular}{lllll}
\hline Hypotheses & $\begin{array}{l}\text { Original } \\
\text { Sample }\end{array}$ & T-statistic & p-value & Description \\
\hline H1 : Job Stress $\rightarrow$ Job Performance & -0.217 & 2.116 & 0.035 & Supported \\
H2: Job Stress $\rightarrow$ Burnout & 0.717 & 16.652 & 0.000 & Supported \\
H3: Job Stress $\rightarrow$ Burnout $\rightarrow$ Job & -0.380 & 4.593 & 0.000 & Supported \\
Performance & & & & \\
\hline
\end{tabular}

\section{Discussion}

The first result of this study reveals that job stress has a negative influence on job performance of the healthcare workers at Aisyiyah Hospital Ponorogo Indonesia at the time of COVID-19 pandemic. It suggests that the higher the level of job stress experienced by the healthcare workers, the lower the level of their job performances, and vice versa. Based on the result analysis, the mean value of job stress experienced by the healthcare workers was classified as low. Moreover, the mean value of job performance was considered high. Hence, it can be concluded that albeit they are working as the fronliners in serving patients during the COVID-19 pandemic, the condition does not cause pressures. As a result, their job performances still remain optimal even during the COVID-19 pandemic.

As depicted in Table 5, there is an interesting finding that although the mean value of job stress is low, the value of psychological dimension is moderate. It indicates that even though the healthcare workers did not experience job stress during the COVID-19 pandemic, they were quite psychologically depressed. They are anxious and afraid of being infected by the virus, being forced to quarantine, and being worried to bring the virus to their family. This result is supported by the findings of Kisely et al. (2020) and Rosyati and Hadi (2020). Moreover, they are also anxious about being negatively seen as a virus carrier by their community and society where they live in. This finding is in line with the result of Nasrullah et al. (2020) and Handayani et al. (2020).

The second finding of this study demonstrates that job stress has a positive influence on burnout experienced by the healthcare workers during the COVID-19 pandemic. It means that the higher the level of the job stress, the higher the burnout felt by the healthcare workers, and vice versa. From the result of data analysis it is shown that the mean value of job stress is classified as low (see Table 5), and so is the mean value of burnout (see Table 6). In a nutshell, although they are working as the frontliners to serve patients during the COVID-19 pandemic, they were lack of feeling under pressure when performing their works and responsibility. It did not cause 
serious emotional exhaustion, depersonalization, and decreased achievement.

This result is certainly in contrast with the finding of Artiningsih and Chisan (2020), stating that the amount of workload and job dissatisfaction contributed to burnout of the healthcare workers. Furthermore, Kisa (2020) revealed that doctors and nurses who were directly contacting with COVID-19 patients were prone to experience stress and decreased internal abilities to perform their works. The different result between this study and the two mentioned previous studies have potentially been due to the availability of the healthcare workers to handle their works, since they are adequate in number, although they did various jobs such as handling patients, check-up, pharmacy, and other services. Hence, they did not experience frustration, emotional exhaustion, and feeling depressed. In addition, the involvement of participants in this study suspected as the cause of the different results. This study recruited not only doctors and nurses who were intensively contacting with COVID-19 patients as what have been conducted by the previous studies, but it also took into account the other medical workers such as pharmacist assistant, midwives, medical record staff, and physiotherapists.

The third result of this study shows that burnout could be a mediating variable of the relationship between job stress and job performance of the healthcare workers during COVID-19 pandemic. This evidence should become a serious consideration for Aisyiyah hospital administers since it can be a risk factor affecting the job performance of the hospital's healthcare workers in the future. A policy should be designed to mitigate the potential risk. This finding supports the statement of the head of Research Team for Masters in Occupational Medicine, Faculty of Medicine, University of Indonesia which stated that if a health worker feels tired emotionally, she/he may experience a clear loss of motivation to work that will potentially give an effect on the job performance.

Overall, albeit the level of job stress and burnout experienced by the healthcare workers still remain low, this study strengthens the findings of previous studies that the situation of health crisis (e.g. COVID-19 pandemic) has potentials to increase stress and burnout among the workers. Hence, this study's results have implications for the interrelated stakeholders, particularly for hospitals and government. The hospital management is expected to implement strategy and program to reduce the job stress and burnout experienced by the healthcare workers, so that it will not affect their job performances and quality of services. As pointed out by Hastuti and Timming (2021), the hospital can develop psychological program interventions to intensify organizational and social supports. Several options can be considered by the hospital such as innovative work shift arrangements (Iswanto, 2020) and the use of technology (Mubaroq \& Insyiroh, 2020) to minimize the direct contact between healthcare workers 
and patients. Moreover, providing the healthcare workers with sufficient space and time to rest as well as vitamin intake and nutritious food are worthy to try.

In a similar direction, appropriate regulation provided by the government to guarantee the safety and mental health of the healthcare workers is required; should be equal to the physical health. Strategic policies such as increasing the number of healthcare workers, providing fair incentives for healthcare workers, and seriously handling the COVID-19 issues are highly necessary. This is in accordance to the statement of Greenberg et al. (2020) that the government should establish an institution that specifically handles mental health for healthcare workers by providing peer support programs, regular meeting times, and psychiatric tele-consultation helplines that have been established to address the mental health problems of health professionals facing overwork.

\section{Conclusion}

To sum up, the in-hand study aims to investigate the effect of job stress on job performance of healthcare workers during the COVID-19 pandemic through the mediating role of burnout. Drawing on the Structural Equation Model involving 194 healthcare workers of Aisyiyah hospital Ponorogo Indonesia, the results reveals that job stress has a negative influence on the performance of the healthcare workers. Moreover, it is found that job stress is proven to have a positive effect on the burnout of the healthcare workers. The results further depict that burnout is found to partially mediate the effect of job stress on the performance of the healthcare workers. These results have several implications and policy recommendations for the hospital and the government.

Despite of the compelling results, this study acknowledges several limitations. First, this study did not classify the healthcare workers who were closely contacted with COVID-19 patients and those who did not. Since this study examines job stress and burnout, it is ideal to determine the population and sample either they are directly contacted with COVID-19 patients or not. It may reach a more tangible result. Hence, future studies are suggested to take into account this factor. Second, this study was conducted at a 'second choice' hospital that generally accepted patients with mild to moderate symptoms. It may potentially affect the level of job stress and burnout of the healthcare workers. Therefore, future research is recommended to conduct similar inquiry by involving participants who are handling COVID-19 patients with severe symptoms and having abundant medical workloads.

\section{Authors' Declaration}

The authors made substantial contributions to the conception and design of the 
study. The authors took responsibility for data analysis, interpretation and discussion of results. The authors read and approved the final manuscript.

\section{ORCID}

Tri Siwi Agustina (D) https://orcid.org/0000-0002-7004-002X

Putri Dian Rarastanti (D) https://orcid.org/0000-0002-7595-957X

Arif Fatah Hidayat (D) https://orcid.org/0000-0003-3896-2224

\section{References}

Abdillah, W., \& Jogiyanto, H. (2015). Partial Least Square (PLS). Yogyakarta: Penerbit Andi.

Alsulimani, L. K., Farhat, A. M., Borah, R. A., AlKhalifah, J. A., Alyaseen, S. M., Alghamdi, S. M., \& Bajnaid, M. J. (2021). Health care worker burnout during the COVID-19 pandemic. Saudi Medical Journal, 42(3), 306-314.

https://doi.org/10.15537/smj.2021.42.3.20200812

Artiningsih, A., \& Chisan, F. K. (2020). Burnout Dan Komitmen Terhadap Tugas: Tantangan Tenaga Medis Dalam Menghadapi Pandemi COVID-19. Seminar Nasional LP3M Universitas Negeri Surabaya, 199-203.

Bakker, A. B., Le Blanc, P. M., \& Schaufeli, W. B. (2005). Burnout contagion among intensive care nurses. Journal of Advanced Nursing, 51(3), 276-287. https://doi.org/ /10.1111/j.1365-2648.2005.03494.x

Bhatnagar, V., Poonia, R. C., Nagar, P., Kumar, S., Singh, V., Raja, L., \& Dass, P. (2021). Descriptive analysis of COVID-19 patients in the context of India. Journal of Interdisciplinary Mathematics, 24(3), 489-504.

https://doi.org/10.1080/09720502.2020.1761635

Deng, J., Guo, Y., Ma, T., Yang, T., \& Tian, X. (2019). How job stress influences job performance among Chinese healthcare workers: A cross-sectional study. Environmental Health and Preventive Medicine, 24(1), 1-11.

https://doi.org/10.1186/s12199-018-0758-4

Elshaer, N. S. M., Moustafa, M. S. A., Aiad, M. W., \& Ramadan, M. I. E. (2018). Job Stress and Burnout Syndrome among Critical Care Healthcare Workers. Alexandria Journal of Medicine, 54(3), 273-277. https://doi.org/10.1016/j.ajme.2017.06.004

Embriaco, N., Papazian, L., Kentish-Barnes, N., Pochard, F., \& Azoulay, E. (2007). Burnout syndrome among critical care healthcare workers. Current Opinion in Critical Care, 13(5), 482-488. https://doi.org/https://doi.org/10.1097/MCC.0b013e3282efd28a

Greenberg, N., Docherty, M., Gnanapragasam, S., \& Wessely, S. (2020). Managing 
mental health challenges faced by healthcare workers during COVID-19 pandemic. BMJ, 368. https://doi.org/10.1136/bmj.m1211

Handayani, R. T., Kuntari, S., Darmayanti, A. T., Widiyanto, A., \& Atmojo, J. T. (2020). Factors Causing Stress in Health and Community When the COVID-19 Pandemic. Jurnal Keperawatan Jiwa, 8(3), 353. https://doi.org/10.26714/jkj.8.3.2020.353-360

Hastuti, R., \& Timming, A. R. (2021). An inter-disciplinary review of the literature on mental illness disclosure in the workplace: implications for human resource management. The International Journal of Human Resource Management, 32(15), 3302-3338. https://doi.org/https://doi.org/10.1080/09585192.2021.1875494

Hira, H., \& Amelia, T. (2020). Healthcare Workers Security: Jaminan, Regulasi, dan Sanksi. Khatulistiwa Law Review, 1(2), 109-129.

Humas FKUI. (2020, September). 83\% Tenaga Kesehatan Indonesia Mengalami Burnout Syndrome Derajat Sedang Dan Berat Selama Masa Pandemi COVID-19. https://Fk.Ui.Ac.Id/Berita/83-Tenaga-Kesehatan-Indonesia-Mengalami-BurnoutSyndrome-Derajat-Sedang-Dan-Berat-Selama-Masa-Pandemi-COVID-19.Html.

Ilpaj, S. M., \& Nurwati, N. (2020). Analisis Pengaruh Tingkat Kematian Akibat COVID-19. Focus: Jurnal Pekerjaan Sosial, 3(1), 16-28. https://doi.org/10.24198/focus.v3i1.28123

Iswanto, A. H. (2020). Innovative work shift for health workers in the health service providers in handling COVID-19 cases. Kesmas, 15(2), 18-23. https://doi.org/10.21109/KESMAS.V15I2.3949

Kisa, S. (2020). Burnout among Physicians and Nurses during COVID-19 Pandemic. European Journal of Environment and Public Health, 4(2), em0055. https://doi.org/10.29333/ejeph/8447

Kisely, S., Warren, N., McMahon, L., Dalais, C., Henry, I., \& Siskind, D. (2020). Occurrence, prevention, and management of the psychological effects of emerging virus outbreaks on healthcare workers: rapid review and metaanalysis. BMJ (Clinical Research Ed.), 369, m1642.

https://doi.org/10.1136/bmj.m1642

Kusumawardani, D. A., Nurika, G., \& Luthfiyana, N. U. (2020). The Mental Health of Medical Workers During the Covid19 Pandemic: How Do We Manage It? Jurnal Kesehatan Lingkungan, 12(1), 21-28. https://doi.org/10.20473/jkl.v12i1si.2020.21-28

Mangkunegara, A. A. A. . (2017). Manajemen Sumber Daya Manusia Perusahaan.

Bandung: Penerbit Remaja Rosdakarya.

Maslach, C., Schaufeli, W., \& Leiter, M. (2017). Job Burnout. Annual Review of Psychology, 52(1), 397-422.

Maunder, R. G., Lancee, W. J., Balderson, K. E., Bennett, J. P., Borgundvaag, B., Evans, 
S., Fernandes, C. M. B., Goldbloom, D. S., Gupta, M., Hunter, J. J., Hall, L. M. G., Nagle, L. M., Pain, C., Peczeniuk, S. S., Raymond, G., Read, N., Rourke, S. B., Steinberg, R. J., Stewart, T. E. \& Wasylenki, D. A. (2006). Long-term psychological and occupational effects of providing hospital healthcare during SARS outbreak. Emerging Infectious Diseases, 12(12), 1924-1932. https://doi.org/10.3201/eid1212.060584

Mubaroq, S., \& Insyiroh, I. M. (2020). Teknologi Kecerdasan Buatan, Big Data Analysis, Dan Internet of Things: Potensi Dan Perannya Dalam Penanganan COVID-19 Di Indonesia. Jurnal Kependudukan Indonesia, (Special Issue), 109-114. https://doi.org/10.14203/jki.v0i0.580

Nabirye, R., Katleen, C., Pryor, E., \& Maples, E. (2011). Occupational stress, job satisfaction and job performance among hospital nurses in Kampala Uganda. Journal of Noursing Management, 19(6), 760-768.

Nasrullah, D., Natsir, M., Twistiandayani, R. R. L., Siswanto, Sumartyawati, N.M Hasanah, U., \& Direja, A. H. (2020). Dampak Psikologis Tenaga Kesehatan dalam Upaya Menghadapi Pandemi Corona Virus (COVID-19) di Indonesia. Kementerian Riset Dan Teknologi - Badan Riset Dan Inovasi Nasional Republik Indonesia. https://sinta.ristekbrin.go.id

Nguyen, N. P. T., Le, D. D., Colebunders, R., Siewe Fodjo, J. N., Tran, T. D., \& Van Vo, T. (2021). Stress and associated factors among frontline healthcare workers in the COVID-19 epicenter of Da Nang city, Vietnam. International Journal of Environmental Research and Public Health, 18(14), 73-78.

https://doi.org/10.3390/ijerph18147378

Ponorogo.go.id. (2021). Pasien Terkonfirmasi COVID-19 Meningkat, Banyak Nakes Terpapar. Pemkab Ponorogo. https://ponorogo.go.id/2021/01/07/pasienterkonfirmasi-meningkat-banyak-nakes-terpapar-COVID-19/

Rizal, J. G. (2020, December 29). Sudah 507 Nakes meninggal Karena COVID-19, Terbanyak Di Bulan Desember. https:/Kompas.Com/Tren/Read/2020/12/29/130000965/Sudah-507-Nakes-Meninggal-Karena-COVID-19-Terbanyak-DiBulan-Desember.

Robbins, S., \& Judge, T. A. (2015). Perilaku Organisasi (16th ed.). Jakarta: Penerbit Salemba Empat.

Rosyanti, L., \& Hadi, I. (2020). Dampak Psikologis dalam Memberikan Perawatan dan Layanan Kesehatan Pasien COVID-19 pada Tenaga Profesional Kesehatan. Health Information: Jurnal Penelitian, 12(1), 107-130. https://doi.org/10.36990/hijp.vi.191

Shah, K., Chaudhari, G., Kamrai, D., Lail, A., \& Patel, R. S. (2020). How Essential Is to Focus on Physician's Health and Burnout in Coronavirus (COVID-19) 
Pandemic? Cureus, 12(4), 10-12. https://doi.org/10.7759/cureus.7538

Syafrida, S., \& Hartati, R. (2020). Bersama Melawan Virus Covid 19 di Indonesia.

SALAM: Jurnal Sosial Dan Budaya Syar-I, 7(6), 495-508.

https://doi.org/10.15408/sjsbs.v7i6.15325

Talaee, N., Varahram, M., Jamaati, H., Salimi, A., Attarchi, M., Dizaj, M. K., Sadr, M., Hassani, S., Farzanegan, B., Monjazeb, F., \& Seyedmehdi, S. M. (2020). Stress and burnout in health care workers during COVID-19 pandemic: validation of a questionnaire. Journal of Public Health: From Theory to Practice, 1-6.

https://doi.org/10.1007/s10389-020-01313-z

Winurini, S. (2020). Permasalahan Kesehatan Mental Akibat Pandemi COVID-19. Info Singkat: Kajian Singkat Terhadap Isu Aktual Dan Strategis, 12(15), 13-18.

Yamin, S., \& Kurniawan, H. (2011). Generasi baru Mengolah Data Penelitian Partial Least Square Path Modelling (1st ed.). Jakarta: Salemba Empat. 